\title{
Preliminary bibliometric evaluation of scientific publications produced in Latin America in the field of tropical and infectious diseases using SciELO
}

\author{
Alfonso J. Rodriguez-Morales ${ }^{1}$, Percy Mayta-Tristán² \\ ${ }^{1}$ Experimental Institute José Witremundo Torrealba (former Center for Parasitological Research JWT), Universidad de Los \\ Andes, Trujillo, and Immunoparasitology Section, Tropical Medicine Institute, Universidad Central de Venezuela, Caracas, \\ Venezuela \\ ${ }^{2}$ Instituto Nacional de Salud, Lima, Perú
}

J Infect Developing Countries 2009; 3(3):247-249.

Received 17 October 2008 - Accepted 27 November 2008

Copyright (C) 2009 Rodriguez-Morales and Mayta-Tristán. This is an open-access article distributed under the Creative Commons Attribution License, which permits unrestricted use, distribution, and reproduction in any medium, provided the original work is properly cited.

Globally, scientific advancement in developing countries relies on many factors and can be evaluated through different means and instruments [1]. In recent years, interest has increased in the ability of publications, commonly measured through different, bibliometric parameters, to estimate the number of available publications and published papers, as well as their usefulness for other researchers globally and regionally $[1,2]$. Although most scientific journals in Latin America are not currently indexed in major databases such as Index Medicus/Medline, Excerpta Medica/Embase and Science Citation Index (SCIISI), new World Health Organization (WHO)/Pan American Health Organization (PAHO)-supported regional databases have emerged as a result of the need for both bibliographical systems for quality qualification and access to full-text articles from these journals. The SciELO (Scientific Electronic Library Online) initiative is one of these databases [3]. SciELO currently comprises 555 journals; 12,140 issues; 182,737 articles; and 3,581,734 citations. Recently, new statistics that enable the analysis of the extent and impact of these regional initiatives tools have been available in this system [3]. Currently this database is the only instrument to measure the impact of such journals because most of them are not indexed in other major databases including SCI-ISI. In other regions such as Asia and Africa, other initiatives have been developed, particularly in Asia where a significant number of journals are indexed in major databases.

For these reasons, we are interested in performing a preliminary evaluation, using data obtained from the SciELO system, on the number of scientific publications production in Latin America, specifically in the field of tropical and infectious diseases. We collected information from all the available journals in the field of tropical and infectious diseases currently indexed on SciELO, and then we retrieved data regarding their impact factor (IF, 2-year based, calculated according to ISI methodology [4] using journals of the SciELO system as data sources, "regional SciELO impact factor"), for all the available years (in some cases since 1999 to 2007) [3]. Journal areas included infectious diseases, tropical diseases and tropical medicine, microbiology, parasitology, and entomology. Our interest focused on describing the number of journals available in this system in the field of tropical and infectious diseases, their impact factor values (mean, standard deviation, SD, range), and the evolution of this parameter for each journal during the studied period.

Currently in the SciELO initiative, 16 journals $(3 \%)$ are available in the field of tropical and infectious diseases. These journals belong to Argentina (1), Brazil (8), Chile (4), Cuba (1) and Venezuela (2). The highest IF registered in the studied period was 0.4769 for the Revista Chilena de Infectología (Chilean Journal of Infectious Diseases), but the highest mean IF corresponded to Revista da Sociedade Brasileira de Medicina Tropical (Journal of the Brazilian Society for Tropical Medicine) with 0.3500 (Figure 1). The maximum variation in the IF during the period was observed in the Revista Chilena de Infectología, with a difference of 0.3936 . The evolution and value variation of the IF was considerable for most journals (Figure 2), specifically 
the Revista da Sociedade Brasileira de Medicina Tropical and the Revista do Instituto de Medicina Tropical de São Paulo (Journal of the São Paulo's Tropical Medicine Institute) (Figure 2). Both journals are indexed in Index Medicus/Medline and SCI-ISI, as well as the recently added Revista Chilena de Infectología, the Brazilian Journal of Infectious Diseases, and Memórias do Instituto journals have occasionally registered an IF higher than 0.25 (Revista do Instituto de Medicina Tropical de São Paulo and Revista Chilena de Infectología) (Figure 1). Surprisingly, the IF for Memórias do Instituto Oswaldo Cruz reached a maximum of 0.740 between 1994 and 2004 according to ISI-Journal Citation Reports ${ }^{\circledR}$. In the Journal Citation Reports for 2003, this journal had 0.688, while the Brazilian

Figure 1. Scientific publications of Latin America in tropical and infectious diseases according to their mean regional SciELO Impact Factors for 1999-2007 (error bars correspond to \pm SD).

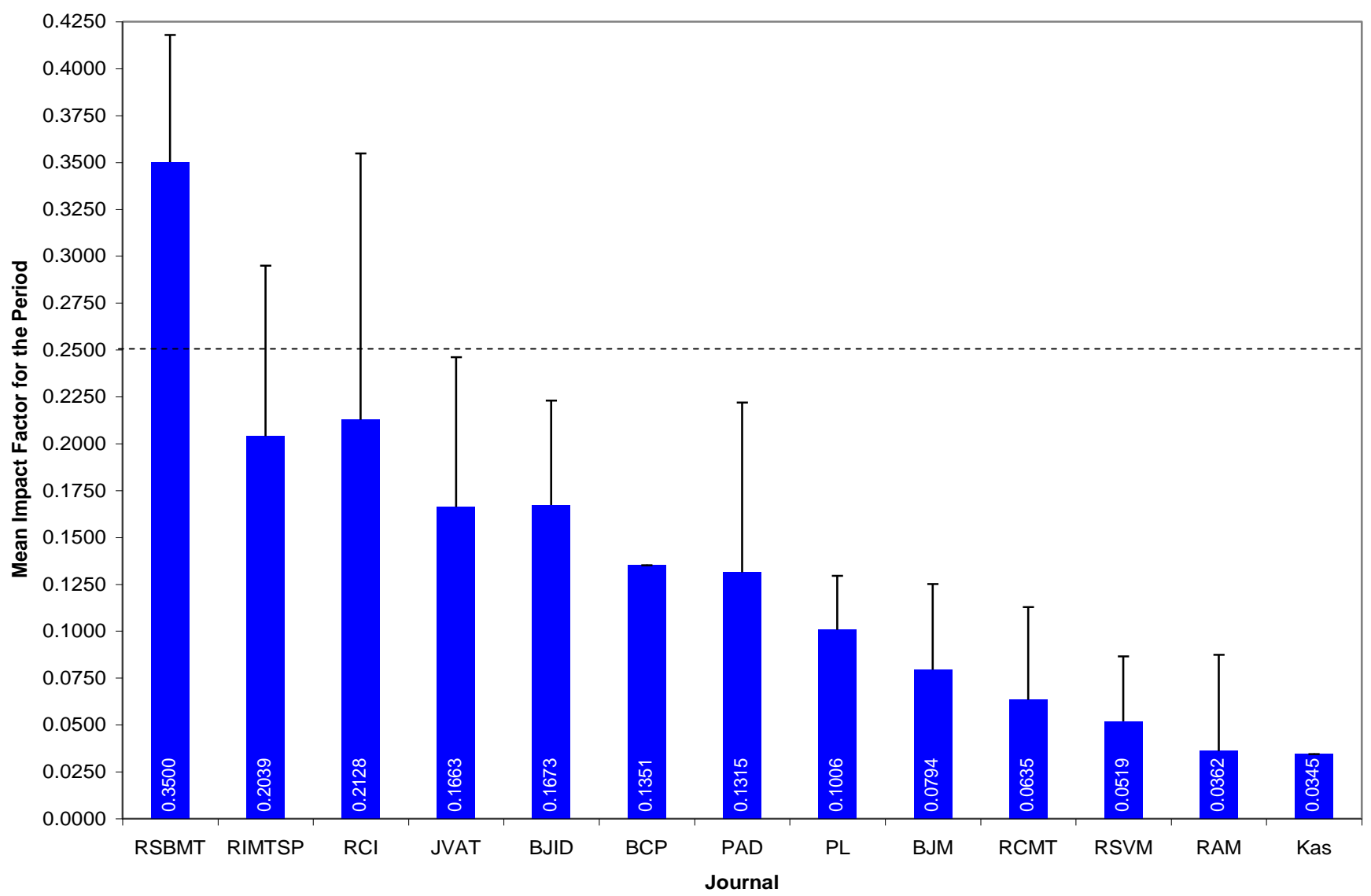

RSBMT, Revista da Sociedade Brasileira de Medicina Tropical; RIMTSP, Revista do Instituto de Medicina Tropical de São Paulo; RCI, Revista Chilena de Infectología; JVAT, Journal of Venomous Animals and Toxins including Tropical Diseases; BJID, Brazilian Journal of Infectious Diseases; BCP, Boletín Chileno de Parasitología; PAD, Parasitología al día; PL, Parasitología Latinoamericana; BJM, Brazilian Journal of Microbiology; RCMT, Revista Cubana de Medicina Tropical; RSVM, Revista de la Sociedad Venezolana de Microbiología; RAM, Revista Argentina de Microbiología; Kas, Kasmera. BCP and PAD were merged and gave rise to PL.

Oswaldo Cruz (also from Brazil). Although Memórias do Instituto Oswaldo Cruz is included in SciELO, data for IF calculations are not yet available.

As seen here, an IF higher than 0.5 had not been reached even for one year by the journal with highest mean IF, indicating that for every two published articles in the two previous journal years, just one is cited in the next year (Figure 1). Moreover, just one journal consistently reached a mean IF higher than 0.25 for the period (Revista da Sociedade Brasileira de Medicina Tropical), and just two additional
Journal of Microbiology (not currently indexed on Index Medicus/Medline) reached 0.170. In the field of tropical and infectious diseases, journals have an average IF of between 0.5 and 6.0, with most of them below 3.0 .

Scientific publication in developing Latin American countries is still very rare [1,2,5-7]. From over 18 million citations currently available in Index Medicus/Medline, only $0.5 \%$ corresponds to Brazil, $0.4 \%$ to Mexico and $0.2 \%$ to Argentina, the three most productive countries in terms of number of 
Figure 2. Time evolution of the Impact Factors of the scientific publications for the period 1999-2007.

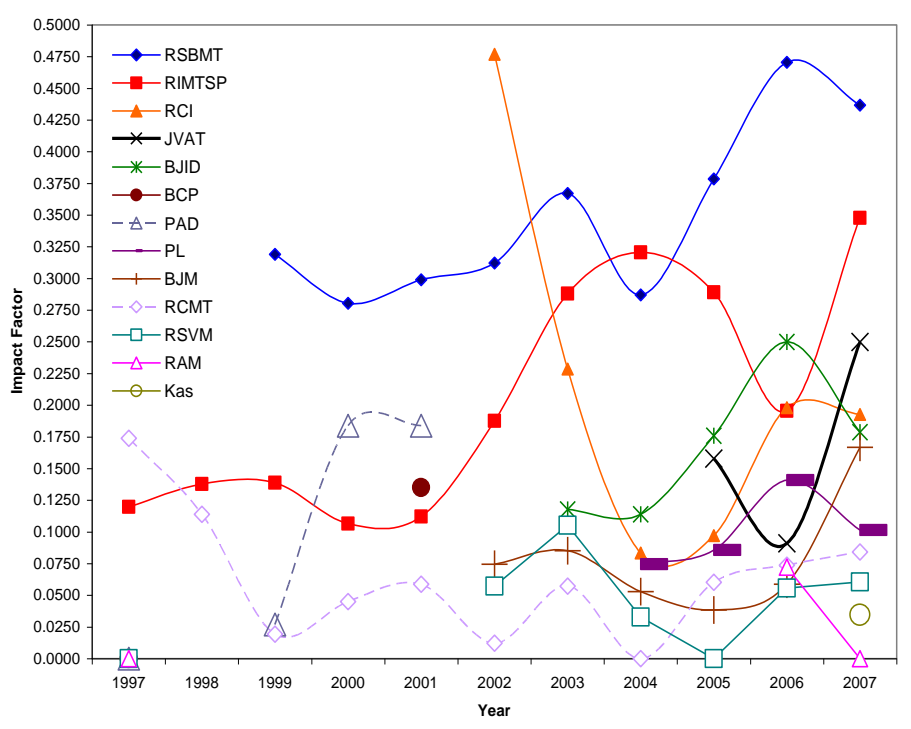

RSBMT, Revista da Sociedade Brasileira de Medicina Tropical; RIMTSP, Revista do Instituto de Medicina Tropical de São Paulo; RCI, Revista Chilena de Infectología; JVAT, Journal of Venomous Animals and Toxins including Tropical Diseases; BJID, Brazilian Journal of Infectious Diseases; BCP, Boletín Chileno de Parasitología; PAD, Parasitología al día; PL, Parasitología Latinoamericana; BJM, Brazilian Journal of Microbiology; RCMT, Revista Cubana de Medicina Tropical; RSVM, Revista de la Sociedad Venezolana de Microbiología; RAM, Revista Argentina de Microbiología; Kas, Kasmera. BCP and PAD were merged and gave rise to PL.

scientific articles published in Medline journals [8]. However, regional initiatives and efforts such as SciELO should be explored and recognized, because they allow the best regional journals to be compiled and the number of citations to these publications to be recorded. The purpose of this system is to connect the regional journals with other major databases. Furthermore, in recent years, the Latin American Federation of Medical Students' Scientific Societies (FELSOCEM) has made additional efforts to train Latin American medical students in the field of scientific publication and editing. This organization has held an annual international congress since 1986. Since 1998, this event has included a Scientific Publishing and Editing meeting which took place in Iquique, Chile, this year [5-7,9]. Scientific publication should be promoted and encouraged in undergraduate studies and should be considered part of the continuing medical education curriculum in order to improve the regional situation [10].
Beyond the limitations of this preliminary assessment, we also considered crucial data and analyses about the production of scientific publications in the region, particularly in the field of tropical and infectious diseases, because diseases such as malaria, leishmaniasis, Chagas disease, dengue fever, schistosomiasis are highly prevalent in many areas across the region, from Mexico to Argentina [11-13].

\section{References}

1. Garcia PJ, Curioso WH (2008) Strategies for aspiring biomedical researchers in resource-limited environments. PLoS Negl Trop Dis 2: e274.

2. Villafuerte-Galvez J, Curioso WH, Miranda JJ (2008) The role of medical students in the fight to control neglected tropical diseases: a view from Peru. PLoS Negl Trop Dis 2: e292.

3. Scientific Electronic Library Online (SciELO) (2008) <http://www.scielo.org>. Accessed 13 October 2008.

4. Thomson ISI (Institute for Scientific Information) (2008) Journal Citation Report (JCR). <http://www.thomsonreuters.com/business_units/scientific/f ree/essays/impactfactor/>. Accessed 14 October 2008.

5. Gutiérrez C, Mayta P (2003) Publicación desde el pre grado en Latinoamérica: Importancia, limitaciones y alternativas de solución. CIMEL 8: 54-60.

6. Huamaní C, Chavez-Solis P, Mayta-Tristán P (2008) Aporte estudiantil en la publicación de artículos científicos en revistas médicas indizadas en SciELO-Perú, 1997 - 2005. An Fac Med (Lima) 69: 42-45.

7. Mayta P (2006) Revistas científicas estudiantiles en Latinoamérica. Rev Med Chil 134: 395-97.

8. PubMed (2008) <http://www.pubmed.com>. Accessed 13 October 2008.

9. Niño Cotrina R, Marañón R, Rodríguez-Morales AJ (2003) FELSOCEM: Visión científica de un pasado, un presente y un futuro. CIMEL 8: 61-62.

10. Huamaní C, Mayta-Tristán P, Rodríguez-Morales AJ (2008). Publicar desde Pregrado. Interciencia 33: 785.

11. Rodriguez-Morales AJ, Benítez JA, Arria M (2008) Malaria mortality in Venezuela: focus on deaths due to Plasmodium vivax in children. J Trop Pediatrics 54: 94-101.

12. Cardenas R, Sandoval CM, Rodriguez-Morales AJ, FrancoParedes C (2006) Impact of climate variability in the occurrence of Leishmaniasis in Northeastern Colombia. Am J Trop Med Hyg 75: 273-77.

13. Von A, Zaragoza E, Jones D, Rodríguez-Morales AJ, Franco-Paredes C (2007) New insights into Chagas Disease: a neglected disease in Latin America. J Infect Developing Countries 1: 99-111. 